\title{
The ketogenic diet: a co-therapy in the treatment of mood disorders and obesity - a case report
}

Dieta ketogenna jako element wspomagający leczenie zaburzeń nastroju i otyłości - opis przypadku

\author{
Agata Pieklik ${ }^{1}$ CEF, Martyna Pawlaczyk ${ }^{1}$ CEF, Joanna Rog ${ }^{2}$ ABCD https://orcid.org/0000-0003- \\ 4057-9507, Hanna Karakuła-Juchnowicz² ABCD, https://orcid.org/0000-0002-5971-795X \\ ${ }^{1}$ Psychiatry Student Research Group I Department of Psychiatry, Psychotherapy and Early Intervention, \\ Medical University of Lublin \\ ${ }^{2}$ I Department of Psychiatry, Psychotherapy, and Early Intervention, Medical University of Lublin
}

\begin{abstract}
Introduction: There has been a growing interest in the ketogenic diet (KD) due to its suggested therapeutic potential to support numerous chronic diseases. KD is characterized by high amounts of fats and a reduced amount of carbohydrates and protein intake. During following the nutrition protocol, ketones are synthesised, which are the primary source of energy. The elevated concentration of ketones in blood serum inhibits hunger, what leads to reduced body weight. Some authors suggest KD has antidepressant potential and could stabilise mood by affecting neurotransmitters homeostasis in the central nervous system.

Material and methods: The aim of the study was to assess the effect of KD on body weight reduction and improvement of mood in the patients with mood disorder diagnosis. To interpret the results of nutritional intervention, the laboratory parameters and structuralised scales and questionnaires were used.

Results: After following 4-week therapy, the reduction of body weight, correction of some laboratory measurements and reduction in mood symptoms were noticed.

Conclusions: The ketogenic diet affects the anthropometric measurements. However, a variety of simultaneous therapeutic approaches makes impossible determination of the effect on depressive symptoms.
\end{abstract}

Keywords: ketogenic diet, mood disorders, depression, nutritional psychiatry, diet

\section{Streszczenie}

Wprowadzenie: $W$ ostatnich latach zainteresowanie dietą ketogenną (DK) znacznie wzrosło, ze względu na jej sugerowany potencjał terapeutyczny we wspomaganiu terapii licznych chorób przewlekłych. DK charakteryzuje się wysokim udziałem tłuszczów oraz ograniczoną ilością spożywanych węglowodanów i białek. Podczas realizacji założeń dietetycznych dochodzi do powstawania ciał ketonowych, które stają się głównym źródłem energii dla organizmu. Podwyższone stężenie ciał ketonowych w surowicy krwi hamuje uczucie głodu, sprzyjając tym samym redukcji masy ciała. Sugeruje się, że DK może wpływać stabilizująco na nastrój, poprzez oddziaływanie na homeostazę neuroprzekaźników w centralnym układzie nerwowym.

Materiał i metody: W niniejszej pracy opisywano przypadek pacjentki hospitalizowanej z powodu nasilenia objawów depresyjnych oraz współwystępującej otyłości. U chorej, oprócz farmakoterapii i psychoterapii, zdecydowano się na zastosowanie interwencji żywieniowej (DK) ze względu na wysoki wskaźnik masy ciała i współwystępowanie zaburzeń metabolicznych. Do interpretacji efektów protokołu żywieniowego wykorzystano wyniki badań laboratoryjnych krwi oraz ustrukturyzowane skale i kwestionariusze.

Wyniki: Po 4 tygodniowej interwencji zaobserwowano znaczący spadek masy ciała chorej, poprawę niektórych parametrów laboratoryjnych krwi oraz stabilizację nastroju.

Wnioski: DK istotnie wpłynęła na poprawę parametrów antropometrycznych, metabolicznych. Jednoznaczna ocena poprawy nastroju nie jest możliwa z uwagi na różnorodność stosowanych jednocześnie metod terapii zaburzeń depresyjnych.

Słowa kluczowe: dieta ketogenna, zaburzenia nastroju, depresja, nutripsychiatria, dieta 


\section{Introduction}

Since 1970, the prevalence of obesity has more than tripled worldwide. It is predicted that the number of individuals with overweight and obesity could rise to $38 \%$ and $20 \%$ respectively in adults population up to the 2030s. The prevalence of obesity can be as high as $85 \%$ in the USA in 2030 [1].

Obesity is a significant risk factor for chronic diseases and a cause of premature death. Cardiovascular diseases, type 2 diabetes, malignant neoplasms, depression, chronic kidney disease and liver disease appear most frequently in its course [2].

The epidemic of obesity and motivation to reduced body weight to recommended values affect rising interest in alternative dietary patterns.

One of the strategies that allow quick bodyweight reduction is a diet with high-fat and low-carbohydrates content (VLCKD - Very Low - Carbohydrate Ketogenic Diet, ketogenic diet: DK). The KD has been used in the therapy of drug-resistance epilepsy for a century [3]. Some studies suggest KD could be helpful as a co-treatment of respiratory and cardiovascular diseases [4].

The mechanism of KD is based on stimulation of hepatic synthesis of ketones [5], which is an effect of cutoff carbohydrates intake under $10 \%$ of daily requirements of energy [6]. The metabolic consequence is shift in energy source from glycolysis to ketogenesis via directs metabolic reaction towards fatty acids or amino acids oxidation. The result is a synthesis of organic compounds named ketones [5]. Acetoacetate, beta-hydroxybutyrate and acetone are the most frequently characterized ketones.

The condition in which the main source of energy are fats is named „ketosis” and in a metabolic way is similar to changes observed during starvation [6]. The nutritional ketosis called "physiological" is characterized by a concentration of ketones between 0.5 and $3 \mathrm{mg} /$ dl [7], compared to 30 to $150 \mathrm{mg} / \mathrm{dl}$ in acidoketosis $[8,9]$. Ketogenic diet leads to "physiological" ketosis and excessive glucose concentration of blood not occurring (what is observed in ketoacidosis: < $250 \mathrm{mg} / \mathrm{dl}$ ) [10]. Acetoacetate and beta-hydroxybutyrate are the primary sources used as alternative energy sources in targeted tissues when glucose levels in blood and glycogen in hepatocytes are insufficient [5]. KD inhibits appetite and evokes the feeling of satiety. DK is recommended to obese and overweight people, including binge eating and food addiction $[4,11]$.

The proposed nutritional protocol of KD is based on the reduction of carbohydrates $(<20-50 \mathrm{~g} /$ daily $)$ and protein (1-1.5 g/kilogram of body weight/daily) and replacing them with sources of fat [7]. The recommended length of following the diet is from 2-3 weeks up to 6-12 months [12].
Additional to favourable effect of body weight reduction and chronic disease, KD could also positively affect mood. Thus, there is suggested potency of diet as an additional therapy to medication in depression [13]. Some reports confirm the efficacy of the protocol in obesity treatment when it is coexisting with mood disorder $[14,15]$.

In the studies, a relationship between depression and GABA-ergic system deficits was observed. GABA (gamma-aminobutyric acid) is a neurotransmitter that affects the inhibition of central nervous system cells. GABA-ergic neurons regulate neuronal systems transmission, including monoaminergic and cholinergic projection from monoaminergic and cholinergic forebrain. GABA affect CNS via activation of ionotropic receptors GABA A and metabotropic receptors GABA B. The GABA $A$ receptors are known to control and alleviate anxiety potent. In patients suffering from mood disorders, low levels of brain GABA was observed. There are hypotheses that dysfunction of the GABA-ergic system is one of the action target antidepressant treatments [16]. So on, KD could be considered an intervention that strengthens pharmacological treatment of drug-resistant depression [13].

The aim of the study is a case report of patients hospitalized due to depressive disorders and comorbid obesity in. The KD was used as an adjunct to the therapy.

\section{Study case and description}

A 21-year-old female, miss, childless with family relations-related problems. Father is an alcohol abuse, and mother is treated for depression. The patient was hospitalized due to bulimia nervosa and mood disorders with suicidal thoughts in 2018. She was suffering from obesity with metabolic syndrome features and hypertension. She was diagnosed with Turner syndrome and received hormone replacement therapy in 2011. The patient had osteosarcoma surgery in 2011, and the treatment was last up to April 2012.

For nine years, the woman has had an eating disorder (manifested by excessive appetite) and emotional disturbance and self-harm to the body.

For six years (since 2015), she has felt sadness, difficulty concentrating and attention, disturbances of circadian rhythms (insomnia shift to excessive sleepiness) and induced vomiting, purging and starving. At the hospitalization time, the body weight was $122 \mathrm{~kg}$, and body mass index (BMI) was $47.66 \mathrm{~kg} / \mathrm{m} 2$ indicating $3 \mathrm{rd}$ degree of obesity.

During the physical examination, the patient reported the presence of suicidal thoughts, felt fear and anxiety. She has 11 points in the Mini-Mental State Examination, which indicates high suicide risk. The blood pressure 
was 169/116 mm Hg (3rd degree of hypertension), heart rate was 101 beats/minute (mild tachycardia). Due to persistently high blood pressure values, captopril was used as an emergency, followed by ramipril, furosemide and amlodipine. The antidepressant treatment included sertraline and trazodone. Laboratory tests revealed high blood glucose, insulin, hepatic enzymes, and coexisted obesity and metabolic syndrome futures, so metformin and tymonacyk were included to the treatment. Patient had vitamin D deficiency, and supplementation was started. The patient also received ethinyloestradiol with levonorgestrel. She received a proposition of realizing nutrition protocol KD. In addition to reducing body weight and improving biochemical parameters, KD would enhance the effectiveness of antidepressants.

To assess the effect of dietary intervention, structured scales and questionnaires were used: the Body Image Questionnaire (KWCO), Scale of satisfaction with parts and parameters of the body, The Scale for the Using of Methods for Correcting Appearance, Scale of Perception of Peer Messages, Scale of Self Constructs and Beck Depression Inventory Scale (BDI). The patient had critical thoughts towards her body and was not entirely sure of diet changes or physical activity, reducing body weight and improving her appearance. On the BDI scale, she received 40 points, which indicate severe depression.

The patient had the willingness and consent to attend to psychotherapy and psychoeducation and implement the dietary intervention. During the hospitalization, she had unstable and lower mood with periods of emotional irritability, tearfulness, increased severity of anxiety and sleep disturbances.

The patient had autoagressive thoughts without the tendency to realize them and had problems adapting to hospital rules.

At the starting point of the diet, her weight was 113.5 $\mathrm{kg}$. The KD based on VLCKD protocol with four meals per day for four weeks was implemented. During the realization nutrition scheme, Kalibra medical protocol was used. The method had been developed in the United States 30 years ago. It included ready-to-eat food products and combining them with an unlimited amount of low-starch vegetables and nutrition supplements. It is necessary to enrich the diet of nutrients due to its low energy value. In Figure 1, an example of a one-day diet plan was shown.

During the therapy, the patient did not report dietrelated health problems. The body mass was reduced from $113.5 \mathrm{~kg}$ to $102 \mathrm{~kg}$, and BMI was $39.9 \mathrm{~kg} / \mathrm{m} 2$, indicating 2nd degree of obesity after the followed diet for four weeks. Despite a high reduction of body weight, the patient was not always willing to cooperate and to follow dietary recommendations. Her motivation had been fluctuated. She was still not satisfied with her appearance.
Breakfast: Focaccia with oregano Kalibra, zucchini ( $1 / 2$ of piece) and green pepper ( $1 / 2$ of piece) stewed on olive oil, a handful of arugula

2nd Breakfast: Rusks Kalibra, cream cheese Kalibra (1 tablespoon), 1 ground cucumber, 5 radishes

Lunch: Shrimp risotto Kalibra

Dinner: Grain bread Kalibra with vegetable spread: mushrooms and aubergine ( $1 / 2$ of piece) stewed on 1 tablespoon of olive oil

Fig. 1.

An improvement in well-being was achieved, the patient's mood was stabilized, the sense of anxiety decreased, and the circadian rhythm was normalized. She also denied the presence of suicidal thoughts. She received 23 points on the BDI scale, indicating moderate depression.

After the intervention, the weight has not been reducing. The diet with a limited amount of simple carbohydrates (so-called "diabetic diet") was recommended during later hospitalization time. At discharge, body weight was $102.7 \mathrm{~kg}$ (BMI $40 \mathrm{~kg} /$ $\mathrm{m} 2$ ), which indicates 3rd degree of obesity. In the continuation of dietary recommendations, systematic consultations were recommended. The patient received an example of a 1-week dietary plan (1500 kcal per day) and general nutritional guidelines/suggestions. She declared willingness to therapy continuation. Below anthropometric measurements and laboratory test results of the patient during hospitalization was depicted.

\section{Discussion}

The presented study case indicates the potential efficacy of KD protocol as a co-therapy of obesity and mood disorder. The patient gradually gets physical and mental health improvement via psychological, pharmacological and dietary intervention during hospitalization.

Her mood stabilizes, the circadian rhythm has been regulated, depression symptoms occur less severe, and body weight was reduced by $20 \mathrm{~kg}$. Following the KD has a positive effect on obesity treatment and improved some of the metabolic syndrome components. The patient did not report headaches, dizziness, fatigue, insomnia, decreased effort tolerance, constipation, nausea, and vomiting. These symptoms are described as a "keto flu” and occur in the implementing, adaptive organism phase for new metabolic conditions, f.e. elevated ketones concentration in blood serum and shift in using the primary energy sources substrates of body. The symptoms go away on their own from few days to weeks $[12,15,17,18,19]$. The quality of life and mood has also been improved, which was indicated by less severity of subjective symptoms. The results of 
intervention studies with individuals with depression indicate a decrease in body weight is accompanied by mood changes [20,21,22].

In a randomized clinical trial, SMILE following the nutrition protocol based on the Meditariean diet was an effective tool in an increase of potent therapy and the decrease mood symptoms [23]. In obese individuals (BMI upon $35 \mathrm{~kg} / \mathrm{m} 2$ ), KD led to reduced body weight, glucose, LDL cholesterol, triglycerides blood concentration, and increased HDL cholesterol concentration [24]. As in our patient, after KD implementation, body weight was decreased, LDL, HDL and total cholesterol concentrations were reduced. The triglycerides level increased and fasting glucose was still maintained above $99 \mathrm{mg} / \mathrm{dl}$. It was unclear wheather in described case, the relationship between KD and reduction of depressive symptoms is causality.

During following nutrition protocol, the patient received antidepressant medication and had psychotherapy and psychoeducation. It is worth mentioning that she could not determine the cause of her mood and behaviour during psychotherapy and moderate depressive symptoms maintained during discharge from the hospital. The nutrition and therapeutic cooperation

Table 1. Subjective assessment scales.

\begin{tabular}{|c|c|c|c|c|}
\hline Scale & \multicolumn{2}{|c|}{ Admission } & \multicolumn{2}{|c|}{ Discharge } \\
\hline Beck Depression Inventory & \multicolumn{2}{|c|}{40 points } & \multicolumn{2}{|c|}{23 points } \\
\hline $\begin{array}{l}\text { The Body Image } \\
\text { Questionnaire }\end{array}$ & \multicolumn{2}{|c|}{10 points } & \multicolumn{2}{|c|}{10 points } \\
\hline $\begin{array}{c}\text { The Scale for the Using of } \\
\text { Methods for Correcting } \\
\text { Appearance }\end{array}$ & \multicolumn{2}{|c|}{28 points } & \multicolumn{2}{|c|}{32 points } \\
\hline \multirow{2}{*}{$\begin{array}{c}\text { Scale of Perception of Peer } \\
\text { Messages }\end{array}$} & Criticism & Complementing & Criticism & Complementing \\
\hline & 13 & 21 & 11 & 22 \\
\hline \multirow[t]{2}{*}{ Scale of Self Constructs } & Criticism & $\begin{array}{l}\text { Positive } \\
\text { opinions }\end{array}$ & Criticism & Positive opinions \\
\hline & 25 & 18 & 20 & 21 \\
\hline
\end{tabular}

Table 2. The measurement of blood pressure and laboratory test results.

\begin{tabular}{|c|c|c|}
\hline Variable & Admission & Discharge \\
\hline $\begin{array}{c}\text { Blood pressure [mm Hg] } \\
\text { Mean of 10 measurements }\end{array}$ & $154 / 98$ & $128 / 72$ \\
\hline $\begin{array}{c}\text { Pulse [beats/minute] } \\
\text { Mean of 10 measurements }\end{array}$ & 93 & 96 \\
\hline $\begin{array}{c}\text { Postpriandal glycemy [mg/dl] } \\
\text { Mean of 7 measurements }\end{array}$ & 127 & 106 \\
\hline CRP [mg/l] & 7.0 & 14.1 \\
\hline Total cholesterol [mg/dl] & 164.9 & 154.8 \\
\hline HDL cholesterol [mg/dl] & 39.3 & 30.5 \\
\hline LDL cholesterol [mg/dl] & 118 & 102 \\
\hline Triglicerydes [mg/dl] & 107 & 122 \\
\hline Insulin [uIU /] & 23.3 & 19.4 \\
\hline D3 Vitamin [ng/ml] & 18.6 & 30 \\
\hline Body weight [kg] & 113.5 & 102 \\
\hline BMI [kg/m2] & 44.3 & 39.9 \\
\hline Fat mass [\%] & 46.9 & 45 \\
\hline Fat mass [kg] & 53.2 & 45.9 \\
\hline Fat-free mass [kg] & 57.2 & 54.6 \\
\hline Total body water [\%] & 40.6 & 42.3 \\
\hline
\end{tabular}


with her was difficult. She did not fully follow dietary recommendations. The patient was not interested in physical activity, and attempts to prompt for physical effort were ineffective.

\section{Conclusions}

The KD was added to pharmacological and psychological therapy for patient's treatment due to high
BMI and her health risk. After the dietary intervention, the body weight was reduced, the metabolic parameters improved. The patient had partial remission of depressive symptoms after followed drug treatment and dietary protocol. In the described study case, the KD is an efficacy as a tool for treatment of obesity. However, determination of the antidepressant potent of protocol is impossible due to using numerous methods of mood disorders treatment simultaneously and lack of patient's cooperation.

\section{Wstęp}

Na całym świecie od lat 70. XX wieku, skala otyłości wzrosła niemal trzykrotnie. Szacuje się, że do 2030 r. liczba osób z nadwagą i otyłością może wynieść odpowiednio 38\% i 20\% dorosłej populacji. W Stanach Zjednoczonych do 2030 r. odsetek ludzi z nadwagą może sięgać aż 85\% [1].

Otyłość jest istotnym czynnikiem ryzyka rozwoju chorób przewlekłych i przyczyną przedwczesnych zgonów. Najczęściej w jej przebiegu pojawiają się choroby układu krążenia, cukrzyca typu 2, nowotwory złośliwe, depresja, przewlekła choroba nerek oraz choroby wątroby [2].

Epidemia otyłości oraz chęć poprawy masy ciała do wartości prawidłowych doprowadziły do wzrostu zainteresowania alternatywnymi wzorcami żywieniowymi.

Jedną ze strategii umożliwiającą szybką redukcję masy ciała jest dieta o wysokiej zawartości tłuszczu i bardzo niskiej zawartości węglowodanów (ang. VLCKD Very Low - Carbohydrate Ketogenic Diet, dieta ketogenna: DK, o niskiej zawartości węglowodanów), która od bez mała wieku stosowana jest w leczeniu lekoopornej epilepsji [3].

$\mathrm{Na}$ przestrzeni ostatnich lat wykazano korzyści płynące ze stosowania DK we wspomaganiu leczenia chorób układu oddechowego i sercowo-naczyniowego [4].

Mechanizm działania DK polega na stymulacji wątrobowej syntezy ciał ketonowych (CK) [5], którą zapoczątkowuje ograniczenie podaży węglowodanów poniżej $10 \%$ dziennego zapotrzebowania [6]. Konsekwencją takiego stanu jest zahamowanie procesu glikolizy na rzecz rozwijającego się procesu ketogenezy, w którym reakcje metaboliczne zwrócone są w kierunku utleniania kwasów tłuszczowych lub utleniania aminokwasów ketogennych [5].

Skutkuje to powstaniem związków ketonowych, a najczęściej opisywane CK to acetooctan, betahydroksymaślan i acetonu [5]. Stan, w których głównym źródłem energii dla organizmu są tłuszcze nosi nazwę „ketozy” i metabolicznie, podobny jest do zmian, które można obserwować podczas procesu głodzenia się [6].
Cechą charakterystyczną ketozy żywieniowej, tzw. „fizjologicznej”, jest stężenie CK w surowicy krwi od 0,5 do $3 \mathrm{mg} / \mathrm{dl}$ [7], w porównaniu z wartościami od 30 do $150 \mathrm{mg} / \mathrm{dl} \mathrm{w}$ kwasicy ketonowej [8,9]. Diety ketonowe powodują „umiarkowaną" ketozę, co nie skutkuje nadmiernym stężeniem glukozy we krwi obserwowanych przy kwasicy ketonowej (<250 mg/dl) [10].

Acetooctan i beta-hydroksymaślan są głównymi związkami wykorzystywanymi jako alternatywne źródła energii $w$ tkankach docelowych, gdy zminimalizowane zostają zapasy glukozy w surowicy krwi i glikogenu w wątrobie [5]. CK hamują uczucie głodu, wywołując tym samym uczucie sytości. DK może być polecana osobom zmagającym się z nadwagą i otyłością oraz w przypadkach napadowego objadania się i w stanach uzależnienia od przyjmowanych pokarmów [4,11].

Proponowany protokół żywieniowy DK opiera się na redukcji węglowodanów (<20-50 g/ dzień) oraz białka (1-1,5 g/kg masy ciała/dzień) w jadłospisie i zastąpienie ich źródłami tłuszczów [7]. Zaleca się stosowanie DK od 2-3 tygodni aż do 6-12 miesięcy [12].

Oprócz pozytywnego wpływu na redukcję masy ciała i choroby ogólnoustrojowe,

DK może również wywierać korzystne działanie na nastrój. Sugeruje jej to możliwe znaczenie w uzupełnieniu terapii farmakologicznej depresji [13]. Istnieją pojedyncze doniesienia potwierdzające skuteczność protokołu w terapii odchudzającej w przypadku otyłości współwystępującej z zaburzeniami nastroju [14,15].

W przeprowadzonych dotychczas badaniach obserwuje się związek między zaburzeniami depresyjnymi a deficytami układu GABA-ergicznego. GABA (ang. gamma-aminobutyric acid, kwas gamma-aminomasłowy) jest neuroprzekaźnikiem pośredniczącym w reakcjach hamowania neuronów ośrodkowego układu nerwowego (OUN). Neurony GABAergiczne równoważą i dostosowywują transmisje układów neuronalnych, w tym projekcje monoaminergiczne i cholinergiczne przodomózgowia. GABA oddziaływuje na OUN poprzez aktywację receptorów jonotropowych GABA A i metabotropowych GABA B. GABA A receptory znane są z funkcji kontrolującej poczucie lęku. U pacjentów 
cierpiących na zaburzenia depresyjnye zauważono niskie stężenie GABA w mózgu. Wysnuwa się hipotezę, iż dysfunkcje układu GABA-ergicznego są jednym z punktów uchwytu działania leków przeciwdepresyjnych [16], dlatego też DK należy rozważyć jako interwencję wspomagającą leczenie farmakologiczne lekoopornej depresji [13].

Celem niniejszego artykułu jest opis przypadku pacjentki hospitalizowanej z powodu zaburzeń depresyjnych i współwystępującej otyłości, u której zastosowano DK jako element wspomagający terapię.

\section{Opis przypadku}

Pacjentka, lat 21, panna, bezdzietna $\mathrm{z}$ trudną sytuacją w relacjach rodzinnych. Ojciec jest uzależniony od alkoholu, matka leczy się z powodu depresji. Chora była hospitalizowana w 2018 r. z powodu zaburzeń odżywiania (bulimia nervosa) oraz zaburzeń nastroju z towarzyszącymi myślami samobójczymi. Kobieta cierpi na otyłość z cechami zespołu metabolicznego oraz nadciśnienie tętnicze. W 2011 r. zdiagnozowano u niej zespół Turnera, z powodu którego przyjmuje hormonalną terapię zastępczą. Jest po operacji osteosarcoma (2011 r.) a leczenie zakończono w kwietniu 2012 r.

U pacjentki od 9 lat występują zaburzenia odżywiania pod postacią nadmiernego apetytu oraz zaburzenia emocji, którym towarzyszą samookaleczania ciała. Od 6 lat (2015 r.) utrzymuje się obniżony nastrój, problemy z koncentracją uwagi, zaburzenia rytmów dobowych pod postacią naprzemiennej bezsenności i nadmiernej senności oraz prowokowanie wymiotów, przeczyszczanie się i głodzenie.

W momencie hospitalizacji pacjentka ważyła 122 $\mathrm{kg}$ a jej BMI było równe 47,66 kg/m2, co wskazywało na 3 stopień otyłości. Podczas badania chora zgłaszała obecność myśli samobójczych, odczuwała lęk i niepokój. W skali MMSE (ang. Mini-Mental State Examination, Krótka Skala Oceny Stanu Psychicznego) uzyskała 11 punktów, co wskazywało na wysokie ryzyko samobójcze. Ciśnienie tętnicze wyniosło 169/116 mm Hg (nadciśnienie tętnicze 3. stopnia), tętno 101 uderzeń/minutę (lekka tachykardia). Z powodu utrzymujących się wysokich wartości ciśnienia tętniczego włączono doraźnie kaptopryl, a następnie ramipryl, furosemid i amlodypinę. Włączono leczenie przeciwdepresyjne sertraliną oraz leczenie nasenne trazodonem. Ze względu na ujawnione $\mathrm{w}$ badaniach laboratoryjnych podwyższone wartości glikemii, insuliny, parametry funkcji wątroby, otyłość i cechy zespołu metabolicznego włączono do leczenia metforminę i tymonacyk. Ze względu na niedobór witaminy D3, rozpoczęto jej suplementację. Oprócz tego chora przyjmowała etynyloestradiol z lewonorgestrelem. Pacjentce zaproponowano także realizację protokołu żywieniowego DK, która oprócz redukcji masy ciała i poprawy parametrów biochemicznych wzmocniłaby działanie leków przeciwdepresyjnych.

Do oceny efektów wynikających z terapii żywieniowej zastosowane ustrukturyzowane skale i kwestionariusze: Kwestionariusz Wizerunku Ciała (KWCO), Skalę zadowolenia z poszczególnych części i parametrów ciała, Skalę Stosowania Metod Poprawiania Wyglądu, Skalę Percepcji Komunikatów Rówieśniczych, Skalę Konstruktów Ja, Inwentarz Depresji Becka (BDI). Pacjentka bardzo krytycznie oceniała swoje ciało, sceptycznie podchodziła do zmian żywieniowych czy aktywności fizycznej mających na celu redukcje masy ciała i poprawę wyglądu. W Inwentarzu BDI otrzymała 40 punktów, co wskazywało na ciężką depresję.

Pacjentka wyraziła chęć i zgodę na wzięcie udziału w psychoterapii, psychoedukacji oraz rozpoczęcie interwencji dietetycznej.

Podczas pobytu w szpitalu, u chorej utrzymywał się zmienny, obniżony nastrój z okresową drażliwością emocjonalną, płaczliwość, nasilenie uczucia lęku i problemy ze snem. Pacjentka werbalizowała myśli o charakterze autoagresywnym bez tendencji do ich realizacji oraz miała problemy z dostosowaniem się do zasad panujących na oddziale szpitalnym. Nawiązywała kontakt z innymi chorymi.

W momencie rozpoczynania diety masa ciała pacjentki wynosiła 113,5 kg (BMI 44,3 kg / m2 - 3. stopień otyłości). Wprowadzono DK, bazującą na protokole VLCKD, z czterema posiłkami dziennie, przez okres 4 tygodni. Podczas realizacji schematu żywieniowego wykorzystano protokół medyczny Kalibra. Metoda została opracowana 30 lat temu w Stanach Zjednoczonych. Polega na zastosowaniu gotowych produktów i połączeniu ich z nieograniczoną ilością warzyw niskoskrobiowych oraz suplementacją. Wzbogacenie diety, ze względu na jej niską wartość energetyczną jest konieczne.

Przykładowy jednodniowy jadłospis przedstawiono na Ryc. 1.

W trakcie terapii chora nie zgłaszała dolegliwości, których wystąpienie wiązałoby się ze stosowaną dietą.

Śniadanie: Foccacia z oregano Kalibra, $1 / 2$ cukinii i $1 / 2$ zielonej papryki duszone na 1 łyżce oliwy $\mathrm{z}$ oliwek, garść rukoli

II Śniadanie: Sucharki Kalibra, kremowy serek Kalibra (1 łyżka), 1 ogórek gruntowy, 5 rzodkiewek

Obiad: Risotto z krewetkami Kalibra

Kolacja: Chleb z ziarnami Kalibra z pastą z warzyw: pieczarki i $1 / 2$ bakłażana podduszone na 1 łyżce oliwy z oliwek

Ryc. 1. 
Po 4-tygodniowej interwencji masa ciała pacjentki spadła o 11,5 kg i wynosiła wówczas $102 \mathrm{~kg}$, BMI było równe $39,9 \mathrm{~kg} / \mathrm{m} 2$, co wskazywało na 2. stopień otyłości. Pomimo znacznej redukcji masy ciała, pacjentka nie zawsze była chętna do współpracy, nie zawsze stosowała się do zaleceń dietetycznych, a jej motywacja ulegała znacznej zmienności. Nadal nie wykazywała zadowolenia z wyglądu swojego ciała. Osiągnięto poprawę samopoczucia, nastrój pacjentki został ustabilizowany, obniżyło się poczucie lęku, znormalizował się rytm dobowy. Pacjentka negowała także występowanie myśli i tendencji samobójczych. W ocenie nasilenia objawów depresyjnych w skali BDI otrzymała 23 punkty, co wskazy wało na umiarkowane nasilenie depresji.

Po zakończeniu realizacji zaleceń DK, masa ciała hospitalizowanej nie uległa dalszej redukcji. W dalszym okresie pobytu w szpitalu zalecono dietę o ograniczonej zawartości węglowodanów prostych (tzw. „dietę cukrzycową") o wartości energetycznej 1500 $\mathrm{kcal} /$ dzień. W momencie wypisu ze szpitala wynosiła 102,7 kg (BMI $40 \mathrm{~kg} / \mathrm{m} 2$ ), co wskazywało na 3 stopień otyłości. Zarekomendowano kontynuację zaleceń żywieniowych, regularne konsultacje dietetyczne. Chora otrzymała przykładowy 1-tygodniowy jadłospis (wartość

Tabela 1. Subiektywne skale oceny.

\begin{tabular}{|c|c|c|c|c|}
\hline Nazwa skali & \multicolumn{2}{|c|}{ Początek hospitalizacji } & \multicolumn{2}{c|}{ Koniec hospitalizacji } \\
\hline Inwentarz Depresji Becka & \multicolumn{2}{|c|}{40 punktów } & \multicolumn{2}{c|}{23 punkty } \\
\hline $\begin{array}{c}\text { Kwestionariusz } \\
\text { Wizerunku Ciała }\end{array}$ & \multicolumn{2}{|c|}{10 punktów } & \multicolumn{2}{|c|}{32 punkty } \\
\hline $\begin{array}{c}\text { Skala Stosowania Metod } \\
\text { Poprawiania Wyglądu }\end{array}$ & \multicolumn{2}{|c|}{28 punktów } \\
\hline $\begin{array}{c}\text { Percepcja Komunikatów } \\
\text { Rówieśniczych [wygląd] }\end{array}$ & Krytyka & Komplementowanie & Krytyka & Komplementowanie \\
\hline \multirow{2}{*}{ Skala uwewnętrznionego Ja } & 13 & 21 & 11 & 22 \\
\cline { 2 - 5 } & Krytyka & Pozytywne opinie & Krytyka & Pozytywne opinie \\
\hline
\end{tabular}

Tabela 2. Zestawienie pomiarów ciśnienia tętniczego, tętna i wyników badań laboratoryjnych.

\begin{tabular}{|c|c|c|}
\hline Rodzaj badania & Początek hospitalizacji & Koniec hospitalizacji \\
\hline $\begin{array}{c}\text { Ciśnienie tętnicze [mm Hg] } \\
\text { Wartość uśredniona 10 pomiarów }\end{array}$ & $154 / 98$ & $128 / 72$ \\
\hline $\begin{array}{c}\text { Tętno [uderzeń / minute] } \\
\text { Wartość uśredniona 5 pomiarów }\end{array}$ & 93 & 96 \\
\hline $\begin{array}{c}\text { Glikemia poposiłkowa [mg / dl] } \\
\text { Wartość uśredniona 7 pomiarów }\end{array}$ & 127 & 106 \\
\hline CRP [mg / l] & 7.0 & 14.1 \\
\hline Cholesterol całkowity [mg / dl] & 164.9 & 154.8 \\
\hline Cholesterol HDL [mg / dl] & 39.3 & 30.5 \\
\hline Cholesterol LDL [mg / dl] & 118 & 102 \\
\hline Triglicerydy [mg / dl] & 107 & 122 \\
\hline Insulina [uIU / l] & 23.3 & 19.4 \\
\hline Witamina D3 [ng / ml] & 18.6 & 30 \\
\hline Masa ciała [kg] & 113.5 & 102 \\
\hline BMI [kg / m2] & 44.3 & 39.9 \\
\hline tkanka tłuszczowa [\%] & 46.9 & 45 \\
\hline tkanka tłuszczowa [kg] & 53.2 & 45.9 \\
\hline masa mięśniowa [kg] & 57.2 & 54.6 \\
\hline nawodnienie [\%] & 40.6 & 42.3 \\
\hline
\end{tabular}


energetyczna $1500 \mathrm{kcal} /$ dzień) oraz ogólne zalecenia żywieniowe. Pacjentka zadeklarowała chęć kontynuacji terapii w warunkach ambulatoryjnych. W poniższych tabelach zostały zaprezentowane pomiary i wyniki badań pacjentki w trakcie całej hospitalizacji.

\section{Dyskusja}

Przedstawiony opis przypadku wskazuje na potencjalne działanie protokołu DK, jako elementu wspomagającego terapię otyłości i zaburzeń depresyjnych. Pacjentka podczas pobytu w szpitalu $\mathrm{w}$ wyniku działań psychologicznych, farmakologicznych oraz dietetycznych stopniowo uzyskała poprawę stanu zdrowia somatycznego oraz psychicznego. Jej nastrój się ustabilizował, rytmy dobowe zostały wyregulowane, objawy depresji stały się mniej uciążliwe a masa ciała została zredukowana o $20 \mathrm{~kg}$.

Zastosowanie DK wywarło pozytywny wpływ na leczenie otyłości i niektórych składowych zespołu metabolicznego pacjentki. Jednocześnie, w trakcie stosowania DK, chora nie zgłaszała obecności objawów takich jak: ból i zawroty głowy, zmęczenie, bezsenność, obniżona tolerancja wysiłku, zaparcia, nudności i wymioty. Symptomy te są opisywane w literaturze jako tzw. „grypa ketonowa" i występują w początkowej fazie adaptacji organizmu do nowych warunków metabolicznych, jakimi są podwyższone stężenia ciał ketonowych w surowicy krwi oraz zmiana wykorzystywanych przez organizm substratów, jako głównego źródła energii. Objawy zwykle ustępują samoistnie w okresie od kilku dni do tygodni [12,15,17-19]. Poprawie uległa także jakość życia, nastrój, o czym świadczy mniejsze subiektywne nasilenie objawów. Wyniki badań interwencyjnych $\mathrm{z}$ udziałem osób ze zdiagnozowaną depresją wskazują, że wraz ze zmniejszeniem masy ciała, obserwowana jest zmiana nastroju [20-22]. W randomizowanym badaniu klinicznym SMILE wykazano, że zastosowanie protokołu żywieniowego opartego na założeniach diety śródziemnomorskiej jest skutecznym narzędziem w zwiększeniu efektywności terapii i zmniejszenia nasilenia objawów depresyjnych [23].

Stosowanie DK u osób z otyłością (BMI powyżej 35 $\mathrm{kg} / \mathrm{m} 2$ ) powodowało spadek masy ciała a także obniżenie poziomu glikemii, lipoprotein o niskiej gęstości (LDL), triglicerydów i cholesterolu, przy jednoczesnym wzroście koncentracji lipoprotein o dużej gęstości (HDL) [24]. U opisywanej pacjentki po zastosowaniu DK zauważono spadek masy ciała, spadek stężenia LDL i HDL oraz nieznaczy spadek stężenia cholesterolu całkowitego. Poziom triglicerydów wzrósł a glikemia na czczo nadal utrzymywała się powyżej $99 \mathrm{mg} / \mathrm{dl}$.

Niejednoznaczne pozostaje czy w opisywanym przypadku DK sama w sobie miała udział we wpływie na redukcję objawów depresyjnych. Pacjentka, w okresie stosowania protokołu żywieniowego, przyjmowała równocześnie leki przeciwdepresyjne oraz uczęszczała na zajęcia z psychoterapii i psychoedukacji. Warto jednak wspomnieć, że chora nie potrafiła w pełni przeanalizować przyczyn swojego nastroju i zachowania podczas trwania psychoterapii, a objawy umiarkowanej depresji utrzymywały się w momencie wypisywania jej ze szpitala. Pacjentka była osobą ciężką we współpracy, zarówno terapeutycznej jak i żywieniowej. Nie w pełni stosowała się do zaleceń dietetycznych. Chora nie przejawiała dużego zainteresowania aktywnością fizyczną, a próby namówienia jej na dodatkowe formy wysiłku nie przynosiły oczekiwanych rezultatów.

\section{Wnioski}

W leczeniu, obok terapii farmakologicznej i psychologicznej, zdecydowano się dodatkowo włączyć DK ze względu na wysoki wskaźnik masy ciała BMI i związane $\mathrm{z}$ tym zagrożenie zdrowia pacjentki. Po interwencji żywieniowej, masa ciała uległa redukcji, poprawie uległy parametry metaboliczne. Pacjentka uzyskała częściową remisję objawów depresyjnych po zakończonej interwencji farmakologicznej i żywieniowej.

Jednoznaczne zatem jest, że w opisywanym przypadku zastosowanie DK jako terapii redukującej masę ciała było skuteczne, jednak ocena jej potencjału przeciwdepresyjnego nie jest możliwa, ze względu na mnogość stosowanych jednocześnie metod leczenia zaburzeń nastroju oraz brak współpracy chorej.

\section{Conflict of interest}

The authors have declared no conflict of interest.

\section{References:}

1. Hruby A, Hu FB. The epidemiology of obesity: A big picture. Pharmacoeconomics. 2015;33:673-689.

2. Pi-Sunyer $X$. The medical risk of obesity. Postgraduate Medicine 2009;121:21-33.

3. Harvey KL, Holcomb LE, Kolwicz SCJr. Ketogenic Diets and Exercise Performance. Nutrients. 2019;11:2296.

4. Owen OE, Morgan AP, Kemp HG, Sullivan JM, Herrera MG, Cahill GFJr. Brain metabolism during fasting. J Clin Invest1967;46:1589-1595.

5. Longo R, Peri C, Cricri D, Coppi L, Caruso D, Mitro N, et al. Ketogenic Diet: A New Light Shining on Old but Gold Biochemistry. Nutrients. 2019; 11(10):2497.

6. Murray RK, Granner KD, Rodwell WV. Biochemia Harpera. Warszawa PZWL. 2015

7. Gershuni VM, Yan SL, Medici V. Nutritional Ketosis for Weight Management and Reversal of Metabolic Syndrome. Curr Nutr Rep. 2018;7(3):97-106.

8. van der Louw E, van den Hurk D, Neal E, Leiendecker B, Fitzsimmon G, Dority L, et al. Ketogenic diet guidelines 
for infants with refractory epilepsy. Eur J Paediatr Neurol. 2016;20(6):798-809.

9. Wlodarek D. Role of Ketogenic Diets in Neurodegenerative Diseases (Alzheimer's Disease and Parkinson's Disease). Nutrients. 2019;11(1):169.

10. Dhatariya K. Blood Ketones: Measurement, Interpretation, Limitations, and Utility in the Management of Diabetic Ketoacidosis. Rev Diabet Stud. 2016;13(4):217-225.

11. Gibson AA, Seimon RV, Lee CMY, Ayre J, Franklin J, Markovic TP, et al. Do ketogenic diets really suppress appetite? A systematic review and meta - analysis. Obes Rev. 2015;16:64-76.

12. Masood W, Annamaraju P, Uppaluri KR. Ketogenic Diet. StarPearls Publishing [Internet]. 2020.

13. Brietzke E, Mansur, RB, Subramaniapillai M, Balanza-Martinez V, Vinberg M, Gonzalez-Pinto A, et al. Ketogenic diet as a metabolic therapy for mood disorders: evidence and developments. Neurosci Biobehav Rev. 2018;94:11-16.

14. Bueno NB, de Melo IS, de Oliveira SL, da Rocha Ataide T. Verylow-carbohydrate ketogenic diet v. Low-fat diet for long-term weight loss: A meta-analysis of randomised controlled trials. $\mathrm{Br}$. J. Nutr. 2013;110:1178-1187.

15. Yancy WSJr, Almirall D, Maciejewski ML, Kolotkin RL, McDuffie JR, Westman EC. Effects of two weight-loss diets on healthrelated quality of life. Qual Life Res. 2009;18:281-289.

16. Luscher B, Shen Q, Sahir N. The GABAergic Deficit Hypothesis of Major Depressive Disorder. Mol Psychiatry. 2011;16(4): 383406.

17. Brinkworth GD, Nokes M, Clifton PM, Buckley JD. Effects of a low carbohydrate weight loss diet on exercise capacity and tolerance in obese subjects. Obesity. 2009;17:1916-1923.

18. Lefevre F, Aronson N. Ketogenic diet for the treatment of refractory epilepsy in children: A systematic review of efficacy. Pediatrics. 2000;105:E46.

19. Grigolon RB, Gerchman F, Schoffel AC, Hawken ER, Gill H, Vasquez $\mathrm{GH}$, et al. Mental, emotional, and behavioral effects of ketogenic diet for non-epileptic neuropsychiatric conditions. Prog
Neuropsychopharmacol Biol Psychiatry. 2020;30:102:109947.

20. Carmen M, Safer DL, Saslow LR, Kalayjian T, Mason AE, Westman EC, et al. Treating binge eating and food addiction symptoms with low - carbohydrate Ketogenic diets: a case series. J Eat Disord. 2020;8:2.

21. 21. Opie RS, O'Neil A, Itsiopoulos C, Jacka FN. The impact of whole-of-diet interventions on depression and anxiety: A systematic review of randomised controlled trials. Public Health Nutr. 2015;18(11):2074-2093

22. Murphy P, Likhodii S, Nylen K, Burnham WM. The antidepressant properties of the ketogenic diet. Biol Psychiatry. 2004;15;56:981 $-983$

23. Jacka FN, O'Neil A, Opie R, Itsiopoulos C, Cotton S, Mohebbi M, et al. A randomised controlled trial of dietary improvement for adults with major depression (the 'SMILES' trial). BMC Med. 2017;15(1):23.

24. Dashti H, Matthew T, Hussein T, Asfar SK, Behbahani A, Khoursheed MA, et al. Long-term effects of a ketogenic diet in obese patients. Exp. Clin Cardiol. 2004;9:200-205

\section{Corresponding author}

Joanna Rog

I Klinika Psychiatrii, Psychoterapii i Wczesnej Interwencji, Uniwersytet Medyczny w Lublinie

ul. Głuska 1, 20-439 Lublin, Polska

e-mail: joannarog@umlub.pl

Otrzymano: 22.07.2021

Zrecenzowano: 27.07.2021

Przyjęto do druku: 03.09.2021 